\title{
National Ignition Facility Project Acquisition Plan
}

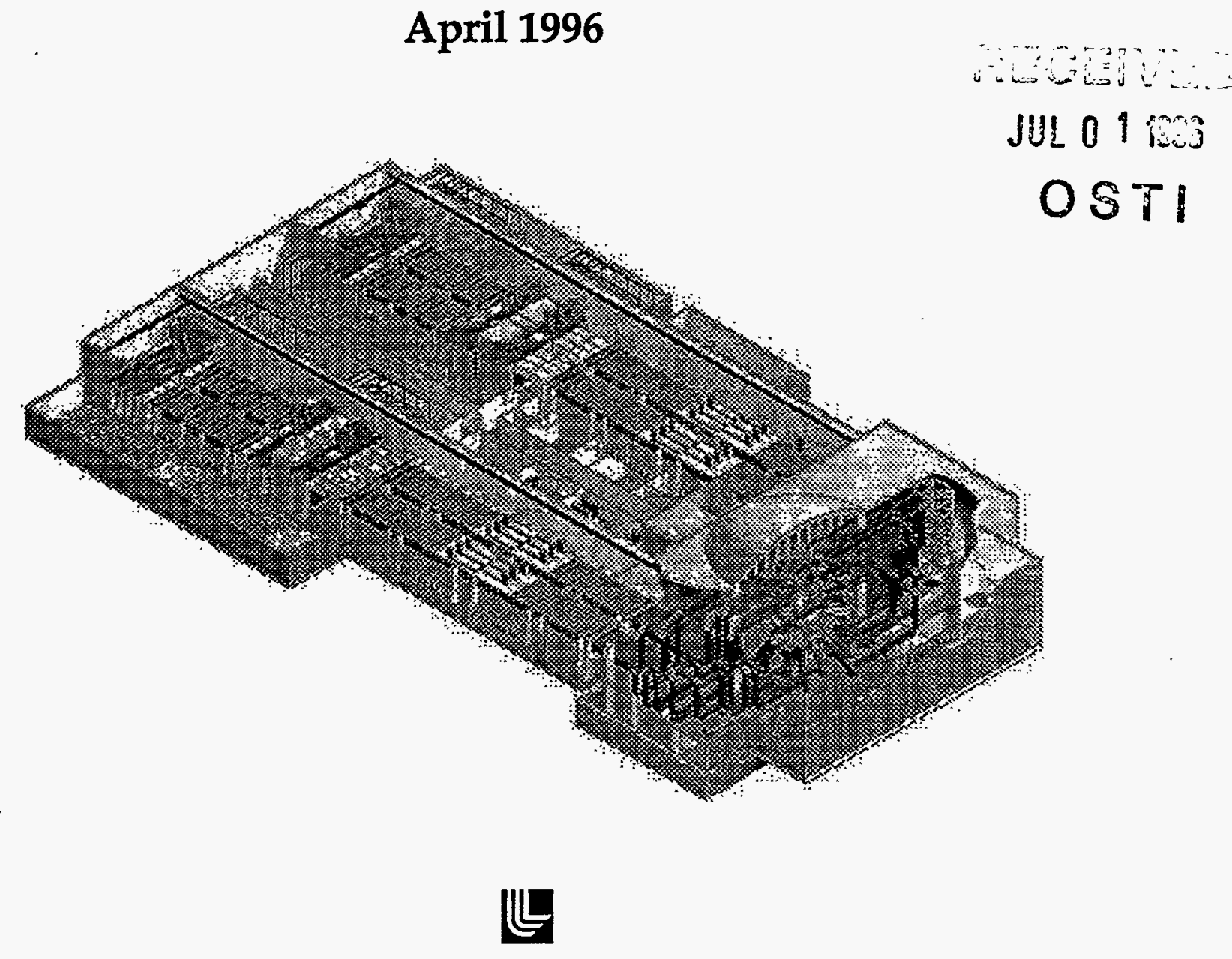

LAWRENCE LIVERMORE NATIONAL LABORATORY

University of California • Livermore, California • 94550 
This document was prepared as an account of work sponsored by an agency of the United States Government. Neither the United States Government nor the University of California nor any of their employees, makes any warranty, express or implied, or assumes any legal liability or responsibility for the accuracy, completeness, or usefulness of any information, apparatus, product, or process disclosed, or represents that its use would not infringe privately owned rights. Reference herein to any specific commercial products, process, or service by trade name, trademark, manufacturer, or otherwise, does not necessarily constitute or imply its endorsement, recommendation, or favoring by the United States Government or the University of California. The views and opinions of authors expressed herein do not necessarily state or reflect those of the United States Government or the University of California, and shall not be used for advertising or product endorsement purposes.

This report has been reproduced directly from the best available copy.

Available to DOE and DOE contractors from the Office of Scientific and Technical Infornation

P.O. Box 62, Oak Ridge, TN 37831

Prices available from (615) 576-8401, FTS 626-8401

Available to the public from the National Technical Information Service

U.S. Department of Commerce

5285 Port Royal Rd., Springfield, VA 22161

This work was performed under the auspices of the U.S. Department of Inergy by Lawrence Livermore National Laboratory under contract no. W-7405-Eng-48. 


\title{
National Ignition Facility Project Acquisition Plan
}

\author{
April 1996
}

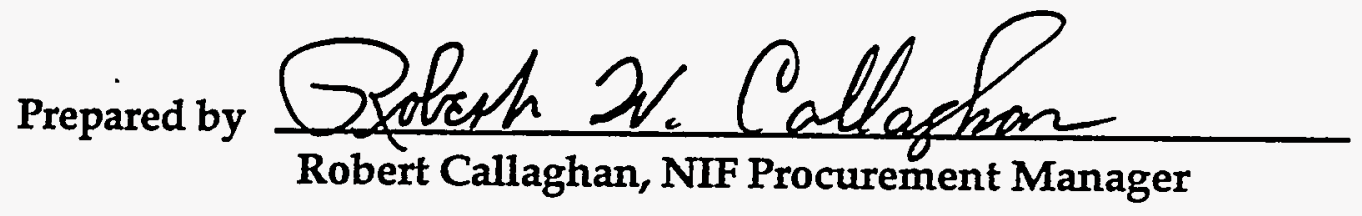





\section{Contents}

1.0 Introduction ............................................................................................................

1.1 Purpose .......................................................................................................... 1

1.2 Scope ............................................................................................................ 1

1.3 Management Approach......................................................................... 1

1.3.1 Institutional Interfaces ............................................................... 2

1.3.2 Work Breakdown Structure........................................................ 2

1.4 Basis........................................................................................................ 4

2.0 NIF Project Funding Plan..................................................................................... 8

2.1 Award Schedule for Procurements .......................................................... 8

3.0 Acquisition Plan ............................................................................................. 10

3.1 Description of the NIF Project Work Activities and Acquisition

Strategy ..................................................................................................... 12

3.1.1 Title I and Title II Design, Title III Engineering (PACE) ......... 12

3.1.2 Optics Manufacturing Facilitization and Pilot Production (OPC) ....................................................................... 13

3.1.3 Construction - Standard Equipment (PACE) ............................ 14

3.1.4 Procurement and Installation-Special Equipment (PACE) ......................................................................................... 15

3.1.5 Start-up and Operating Spares (OPC) ........................................ 16

3.2 Source Selection ............................................................................................. 17

3.2.1 Methods of Obtaining Competition ............................................. 17

3.2.2 Source Selection Procedures........................................................... 17

3.2.3 Solicitation Documentation ........................................................ 17

3.2.4 Evaluation Criteria....................................................................... 19

3.3 Vendor Qualification ..................................................................................... 19

3.4 Representative Major Contractors/Suppliers....................................... 20

3.5 Socioeconomic Programs ....................................................................... 20

3.6 Site Selection and Acquisition of Real Property .................................... 21

3.7 Anticipated Organizational Conflict of Interest Concerns.................... 21

3.8 Patents and Data............................................................................................ 21

3.9 Receipts (Royalty) ............................................................................................ 21

3.10 Other Information .......................................................................................... 21

3.10.1 Contract Labor................................................................................. 22

3.10.2 Advance Procurement Request (Long-Lead

Procurements) ............................................................................... 22

3.10.3 Other Optics Considerations........................................................ 22

3.11 Non-Government Participation................................................................... 23 
4.0 Project Risks ............................................................................................ 24

4.1 Technical Risk .............................................................................................. 25

4.2 Cost Risk................................................................................................. 26

4.3 Schedule Risk .................................................................................................... 26

5.0 Reporting .................................................................................................................. 28

6.0 Notes and References ....................................................................................... 29

Appendix A ................................................................................................................. 30

\section{Figures}

1. NIF project organization ....................................................................................... 3

2. National Ignition Facility Work Breakdown Structure ................................... 4

3. NIF Summary Integrated Project Schedule .......................................................... 6

\section{Tables}

1. NIF Project Baseline Costs ........................................................................................... 8 


\section{Terms and Acronyms}

ATP

$\mathrm{AE}$

BA

$\mathrm{BO}$

CBD

$\mathrm{CD}$

$\mathrm{CM}$

CPAF

CPFF

CPIF

DOE

DOE-DD

DOE-HQ

ESAAB

ES\&M

Facilitization

FFP

FPI

FY

GFE

GFP

GSO

ICF

$\mathrm{KD}$

LANL

LLNL

LTAB
Acceptance Test Procedure

Architect-Engineer

Budget Authority (appropriation providing authority to enter into obligations resulting in immediate or future outlays of Government funds)

Budget Outlay (outlay of Government funds)

Commerce Business Daily

Critical Decision

Construction Manager

cost plus award fee

cost plus fixed fee (contractor is reimbursed for actual allocable and allowable costs plus a fixed fee established at the inception of the contract that will not vary according to the cost incurred)

Cost plus incentive fee

Department of Energy

Department of Energy Defense Programs

Department of Energy Headquarters

Energy Systems Acquisition Advisory Board

environmental, safety, and health

The acquisition of plant equipment, and its provision as governmentfurnished property, to increase manufacturing capability to allow a subcontractor to fabricate material and components at the rate and quality level required

Firm Fixed Price (provides for a price that is not subject to any adjustment on the basis of the subcontractor's cost experience in performing the contract)

fixed-price incentive

fiscal year

government-furnished equipment

government-furnished property

Goods and Services on Order

Inertial Confinement Fusion

Key Decision

Los Alamos National Laboratory

Lawrence Livermore National Laboratory

Laser and Target Area Building 


\section{Terms and Acronyms (Cont.)}

$\mathrm{M} \& \mathrm{O}$

MRB

MTA

NEPA

NIF

$\mathrm{OAB}$

OCI

OPC

OPEX

ORR

PACE

PEP

Pilot

production

QA

QC

RFP

RFQ

ROD

Single Source

SNL

Sole Source

SOW

Special

Equipment

Standard Equipment

Subcontract

TEC
Management and Operating Contractor, e.g., University of California for LANL and LLNL, Lockheed-Martin for Sandia, University of Rochester for UR-LLE

Materials Review Board

Master Task Agreement

National Environmental Policy Act

National Ignition Facility

Optical Assembly Building

Organizational Conflict of Interest

Other project costs

Operating Expense (funding type)

Operational Readiness Review

Plant and Capital Equipment (funding type)

Project Execution Plan

Pre-production articles fabricated to demonstrate capability of the subcontractor and the production equipment to manufacture the quality and quantity of a product.

quality assurance

quality control

Request for Proposal

Request for Quotation

Record of Decision

Restricting solicitation to one source based on a determination that the selected source offers the best value to the requester over other potentially qualified sources.

Sandia National Laboratories

Restricting solicitation to one source based on a determination that only that source is capable of meeting project requirements.

Statement of Work

Equipment, including lasers, optics, target systems, and diagnostics bought by the NIF Project Office. Also includes engineered support equipment-instrumentation, physical security, computer control system and monitoring equipment.

Heating ventilation and air conditioning (HVAC), electrical and other mechanical and utility support equipment.

Legally binding agreement issued under an $M \& O$ prime contract, between an $M \& O$ and a third party, that contains the essential terms and conditions under which goods and/or services will be furnished to the M\&O. Includes purchase orders.

Total Estimated Cost 


\section{Terms and Acronyms (Cont.)}

TPC

$\mathrm{UC}$

UR-LLE

WBS
Total Project Costs (equal to the sum of TEC and OPC)

University of California

University of Rochester, Laboratory for Laser Energetics

Work Breakdown Structure 
NIF-LLNL-96-251

L-16865-2

May 6, 1996

vi 


\subsection{Introduction}

\subsection{Purpose}

The purpose of this National Ignition Facility Acquisition Plan is to describe the overall procurement strategy planned for the National Ignition Facility (NIF) Project. It was prepared for the NIF Project Office by the NIF Procurement Manager.

\subsection{Scope}

The scope of the plan describes the procurement activities and acquisition strategy for the following phases of the NIF Project, each of which receives either plant and capital equipment (PACE) or other project Cost (OPC) funds:

- Title I and II design and Title III engineering (PACE).

- Optics manufacturing facilitization and pilot production (OPC).

- Convention facility construction (PACE).

- Procurement, installation, and acceptance testing of equipment (PACE).

- Start-up (OPC).

Activities that are part of the base Inertial Confinement Fusion (ICF) Program are not included in this plan.

The University of California (UC), operating Lawrence Livermore National Laboratory (LLNL) and Los Alamos National Laboratory, and Lockheed-Martin, which operates Sandia National Laboratory (SNL) and the University of Rochester Laboratory for Laser Energetics (UR-LLE), will conduct the acquisition of needed products and services in support of their assigned responsibilities within the NIF Project structure in accordance with their prime contracts with the Department of Energy (DOE). LLNL, designated as the lead Laboratory, will have responsibility for all procurements required for construction, installation, activation, and startup of the NIF.

\subsection{Management Approach}

Overall DOE management responsibilities were first stated in the approved Project Charter ${ }^{1}$ signed in March 1993. Since then, the DOE's Office of the National Ignition Facility was established to interpret, explain, and defend the role of the NIF Project and provide executive-level project control for the DOE. 
A DOE Memorandum of Understanding, ${ }^{2}$ approved in May 1995, contains more recent and specific DOE management responsibilities and interfaces agreed to between DOE's Office of the National Ignition Facility and Office of Research and Inertial Fusion. Management roles and responsibilities are defined in the National Ignition Facility Project Execution Plan (draft). ${ }^{3}$

The key management positions are:

1. Director, Office of the National Ignition Facility-responsible for the DOE-HQ roles for formulating policy, budget authorization, and overall project direction.

2. Director, Office of Research and Inertial Fusion-responsible for ensuring that National Inertial Confinement Fusion Program goals are achieved and the technology basis required for the NIF is developed.

3. NIF DOE-Field Manager-responsible for the formal day-to-day onsite management oversight; cost and schedule control; and environment, safety, and health requirements.

4. NIF Laboratory Project Manager-responsible for implementing the Project and directing the participating laboratories and other contractors (such as architect/engineers, construction manager, and engineering support).

5. Laboratory Deputy Project Managers-responsible for supporting the NIF Laboratory Project Manager in the project implementation while representing their institution.

The NIF Project Manager is supported by Deputy Project Managers representing each participating organization: LANL, SNL, LLNL, and UR-LLE and key line and staff personnel. Figure 1 depicts the formal NIF Project Management Structure. All NIF Procurements are carried out by dedicated Laboratory procurement teams appropriate to the size and number of the procurement actions at each participating Laboratory reporting to the NIF Procurement Manager. These teams will operate in accordance with their DOE-approved procurement systems. In addition, subcontractors such as the Architect-Engineer (AE), Construction Manager (CM), and National Environmental Policy Act (NEPA) Document preparer will be involved in the implementation of the Project.

\subsubsection{Institutional Interfaces}

Each institution will participate in the manner prescribed in the Project Execution Plan (PEP). The Deputy Project Managers will direct the required resources at their respective institutions in support of the roles and responsibilities defined in the PEP. The Deputies will also manage the flow of information between organizations. This will be accomplished by formal and informal correspondence and periodic meetings.

\subsubsection{Work Breakdown Structure}

The Work Breakdown Structure (WBS) shown in Figure 2 has been developed as a basis for project planning and control. 


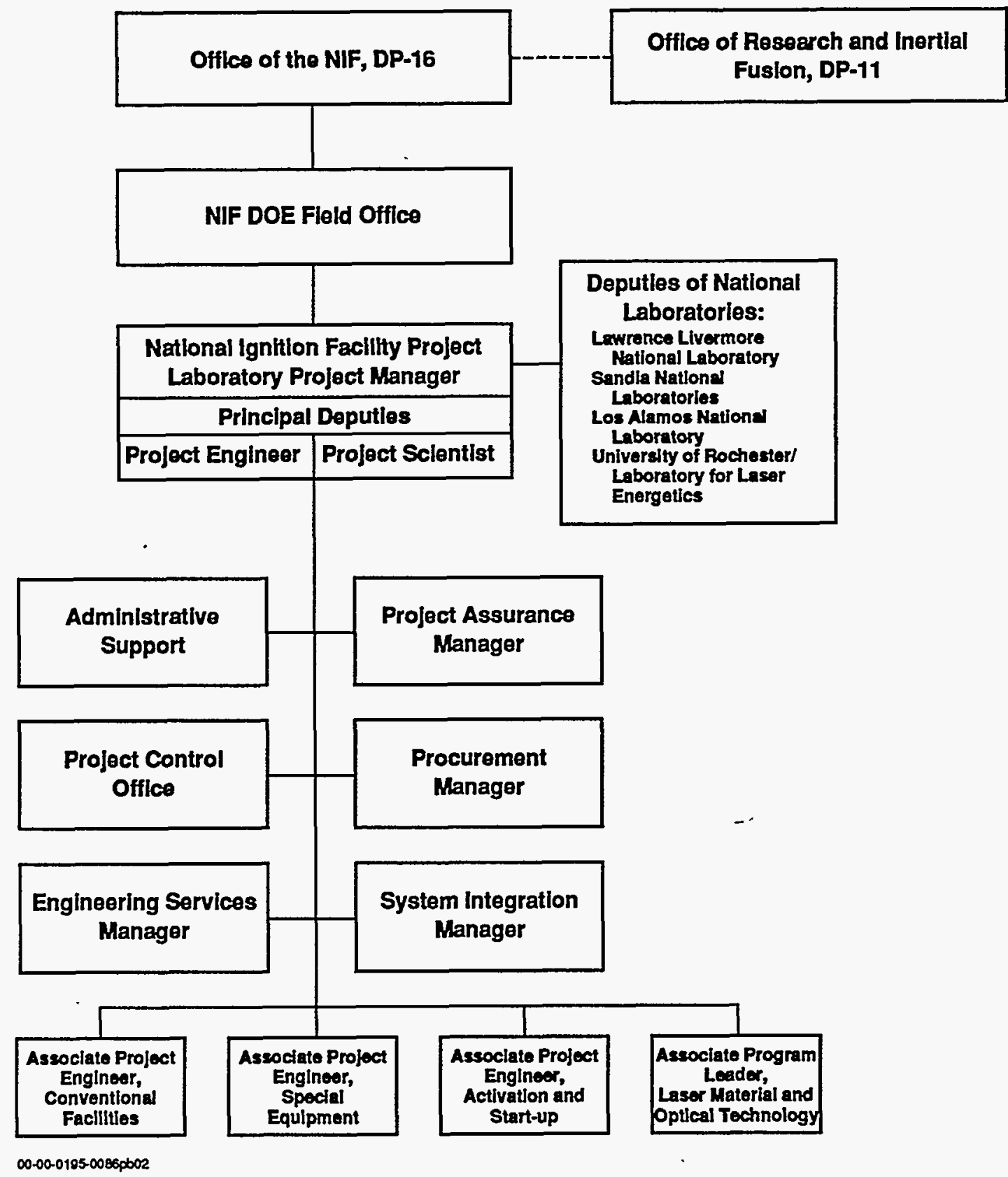

Figure 1. NIF project organization. 


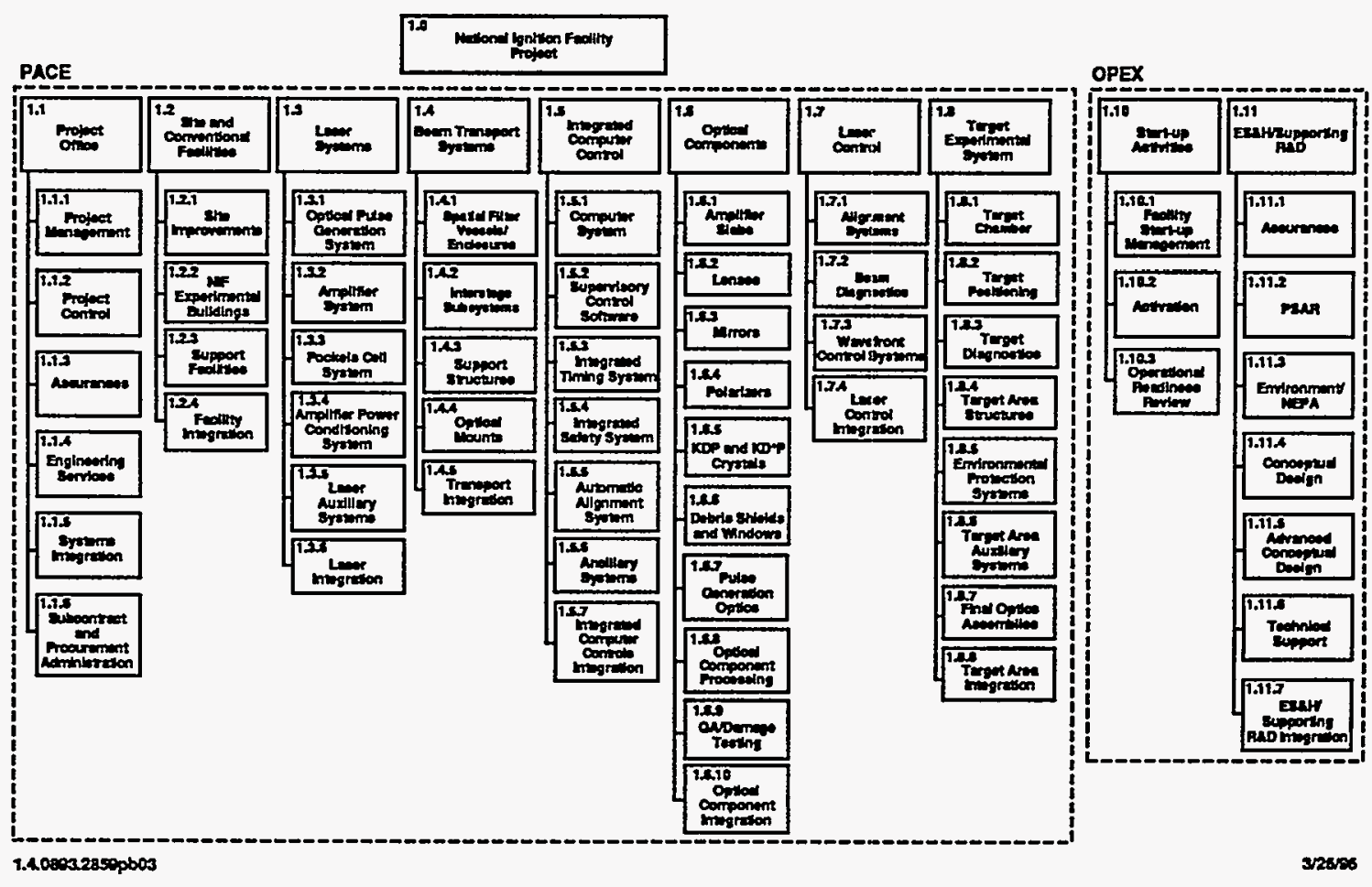

Figure 2. National Ignition Facility Work Breakdown Structure.

\subsection{Basis}

The following schedule and accompanying cost basis were used for this Plan:

\section{General}

- The NIF will be a Strategic System.

- The integrated schedule and the Total Project Costs (TPC) were established with the Critical Decision 0, which was approved by the DOE Secretary of Energy in January 1993.

- The NIF scope is defined by the National Ignition Facility Functional Requirements/Primary Criteria, ${ }^{4}$ and is detailed further in the National Ignition Facility Conceptual Design Report ${ }^{5}$ and supporting cost/schedule baselines.

- The NIF is a national activity and will be implemented by a multilaboratory project via a Memorandum of Agreement between Laboratory participants under contract to DOE.

- Total Project Costs include both Plant and Capital Equipment (PACE) funded Total Estimated Cost (TEC) and Operating Expense (OPEX) funded Other Project Costs (OPC). Detailed definitions of TEC and OPC cost are contained in the 
National Ignition Facility Conceptual Design Scope and Plan 6 and the NIF Project Congressional data sheets.

Primary procurement costs in the NIF project TEC (PACE):

- The principal procurement costs included in the TEC are the conventional facilities and standard equipment, special equipment, optical components, equipment assembly and installation, and contract labor.

\section{Primary procurement costs in the NIF Project OPC:}

- The principal procurements included in the OPC are NEPA process support, government-furnished equipment for optics manufacturing facilitization, optics pilot production, preproduction prototypes, initial operating spares and selected target diagnostics, and facility activation and start-up.

\section{Siting:}

- Construction of a new facility will be at a DOE site to be determined through the NEPA process.

- Although the NIF site has not been selected, the KD1 letter from the DOE Secretary of Energy specified Lawrence Livermore National Laboratory as the preferred site. Other candidate sites are Los Alamos National Laboratory, Sandia National Laboratory-New Mexico, and the Nevada Test Site (2 locations). Final site selection will result from the Stockpile Stewardship and Management Programmatic Environmental Impact Statement through the Record of Decision.

\section{Schedule Basis:}

- The NIF Summary Integrated Project Schedule is shown in Figure 3.

- The following Architect-Engineer (AE) subcontractors for Title I and II facility engineering designs, selected in January 1996, will be under a subcontract by May 1996.

- Ralph M. Parsons, for the Laser Target Area Building (LTAB). (February, 1996)

- A. C. Martin, for the Optical Assembly Building (OAB). (estimated May, 1996)

- Specific long-lead procurements will be required during of Title II design to maintain project completion in FY02. These long-lead procurements include items such as large optics, target chamber, materials, and other special equipment.

- Site selection decision by the Secretary is scheduled for September, 1996 based on the NEPA Record of Decision (ROD), and construction will begin third quarter of FY97.

- Sverdrup Facilities, selected as Construction Manager (CM) in January 1996, will be subcontractor for the conventional facilities and standard equipment. The subcontract will be awarded in the fourth quarter FY96 to begin planning for construction. The $\mathrm{CM}$ will assist in the preparation of bid packages for the construction trades. Laboratory procurement resources will award the 
subcontracts and the $\mathrm{CM}$ will perform the technical subcontract administration for the Laboratory.

- The NIF construction, assembly, installation, and start-up phases will overlap. Beneficial occupancy of the facilities will be obtained in phases. Contracting strategy will recognize the need for careful coordination to prevent interference between contractors performing facility construction and installation of hardware.

- Government-furnished equipment (GFE) for vendors is necessary to provide the optics manufacturing capacity required to meet the project schedule. This facilitization effort will begin in the second quarter of FY96.

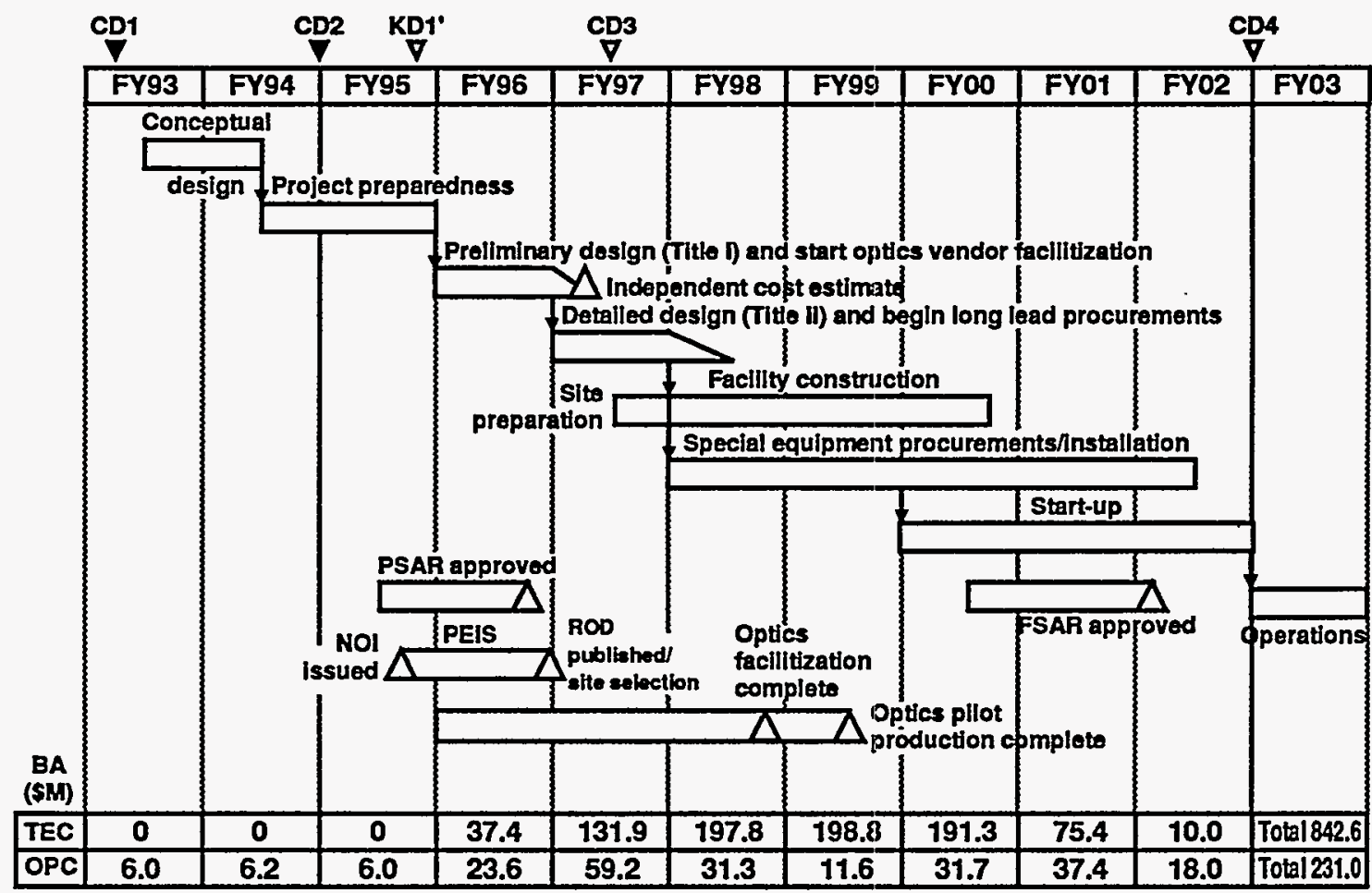

$\begin{array}{ll}\text { CD1 } & \text { Approve mission need } \\ \text { CD2 } & \text { Approve new start } \\ \text { KD1' } & \text { Dellum's Process NIF Study complete } \\ \text { CD3 } & \text { Approve construction start } \\ \text { CD4 } & \text { Approve operation start }\end{array}$

40-00-0105-0269pb05

Figure 3. NIF Summary Integrated Project Schedule. 
- Pilot production subcontracts will be used to confirm the ability of the optics subcontractors' manufacturing processes and procedures to comply with quality, quantity, and schedule requirements. Subcontracts for production runs are contingent on successful pilot production.

- Initial operating spare optics will be fabricated in FY01 at the conclusion of the production of the optics for initial facility assembly. They will be procured as part of the main production subcontracts to minimize costs. Some additional operating spares may be obtained during pilot production.

- Start-up and facility activation will begin in FY01 and end in FY02.

\section{Contract labor/Master Task Agreements}

- The NIF will use, wherever appropriate, contract labor and Master Task Agreements (MTAs) to obtain additional labor required to accomplish the project schedule.

\section{Relationship to core ICF Program}

- Core Science and Technology development activities, ${ }^{7}$ which are part of the ongoing ICF Program are outside the scope of the NIF project, and will be supported by ICF Program operating funds. Procurements in this area are not addressed in this Plan although they are important to the successful completion of the NIF Project. 6 


\subsection{NIF Project Funding Plan}

\subsection{Award Schedule for Procurements}

The NIF Procurement Plan, scheduled to be completed at end of the fourthquarter FY96, will provide a more comprehensive procurement schedule consistent with the summary project schedule developed at the completion of Title I design. The NIF Annual Financial schedule and Annual Cost Plan at WBS Level 2 are shown in Table 1.

Table 1. NIF Project Baseline Costs.

NIF Annual Financial Schedule (Escalated \$M)

\begin{tabular}{|c|c|c|c|c|c|c|c|c|c|c|c|}
\hline & FY93 & FY94 & FY95 & FY96 & FY97 & FY98 & FY99 & FY00 & FY01 & FY02 & Total \\
\hline \hline Total Estimated Cost & & & & & & & & & & & \\
\hline BA & - & - & - & 37.4 & 131.9 & 197.8 & 198.8 & 191.3 & 75.4 & 10.0 & 842.6 \\
\hline BO & - & - & - & 37.4 & 49.5 & 176.7 & 233.8 & 184.4 & 113.3 & 47.5 & 842.6 \\
\hline Other Project Cost & & & & & & & & & & & \\
\hline BA & 6.0 & 6.2 & 6.0 & 23.6 & 59.2 & 31.3 & 11.6 & 31.7 & 37.5 & 17.9 & 231.0 \\
\hline BO & 2.6 & 9.6 & 6.0 & 20.9 & 46.5 & 43.8 & 11.6 & 31.1 & 40.9 & 18.0 & 231.0 \\
\hline Total Project Cost & & & & & & & & & & & \\
\hline BA & 6.0 & 6.2 & 6.0 & 61.0 & 191.1 & 229.1 & 210.4 & 223.0 & 112.9 & 27.9 & $1,073.6$ \\
\hline BO & 2.6 & 9.6 & 6.0 & 58.3 & 96.0 & 220.5 & 245.4 & 215.5 & 154.2 & 65.6 & $1,073.6$ \\
\hline
\end{tabular}


Table 1. (Cont.)

NIF Annual Cost Plan at WBS Level 2 (Escalated \$M)

\begin{tabular}{|c|c|c|c|c|c|c|c|c|c|c|c|c|}
\hline \multicolumn{13}{|l|}{ Total Estimated Cost } \\
\hline & WBS & FY93 & FY94 & FY95 & FY96 & FY97 & FY98 & FY99 & FYOO & FY01 & FY02 & Total \\
\hline Project Office & 1.1 & & & & 8.9 & 4.3 & 5.3 & 6.2 & 5.9 & 4.5 & 2.6 & 37.6 \\
\hline $\begin{array}{l}\text { Site \& Conventional } \\
\text { Facilities }\end{array}$ & 1.2 & & & & 5.2 & 12.8 & 69.5 & 52.8 & 4.2 & 0.6 & 0.1 & 145.2 \\
\hline Laser Systems & 1.3 & & & & 4.1 & 4.0 & 34.8 & 363 & 54.3 & 28.2 & 1.4 & 163.2 \\
\hline $\begin{array}{l}\text { Beam Transport } \\
\text { System }\end{array}$ & 1.4 & & & & 3.4 & 3.4 & 17.3 & 31.4 & 16.3 & 16.8 & 2.4 & 91.0 \\
\hline $\begin{array}{l}\text { Integrated Computer } \\
\text { Control }\end{array}$ & 1.5 & & & & 2.1 & 2.1 & 2.5 & 4.4 & 4.2 & 22 & 0.1 & 17.6 \\
\hline Optical Components & 1.6 & & & & 1.1 & 1.4 & 3.0 & 21.9 & 37.2 & 33.5 & 30.8 & 128.9 \\
\hline Laser Control & 1.7 & & & & 22 & 3.5 & 5.1 & 17.4 & 21.5 & 5.6 & 2.2 & 57.6 \\
\hline $\begin{array}{l}\text { Target Experimental } \\
\text { System }\end{array}$ & 1.8 & & & & 4.4 & 8.5 & 8.0 & 23.4 & 10.4 & 2.1 & 0.9 & 57.7 \\
\hline Subtotal & & 0.0 & 0.0 & 0.0 & 31.4 & 40.1 & 145.6 & 193.7 & 154.0 & 93.6 & 40.4 & 698.7 \\
\hline Contingency & & & & & 6.0 & 9.4 & 31.1 & 40.1 & 30.4 & 19.7 & 7.2 & 143.9 \\
\hline \multicolumn{2}{|c|}{ Total PACE Funded } & 0.0 & 0.0 & 0.0 & 37.4 & 49.5 & 176.7 & 233.8 & 184.4 & 113.3 & 47.6 & 842.6 \\
\hline \multicolumn{13}{|l|}{ Other Project Cost } \\
\hline Start-up Activities & 1.10 & & & & 0.7 & 20 & 2.6 & 5.5 & 25.1 & 32.7 & 16.5 & 85.1 \\
\hline $\begin{array}{l}\text { ES\&H Supporting } \\
\text { R\&D }\end{array}$ & 1.11 & 2.6 & 9.6 & 6.0 & 20.2 & 44.5 & 41.2 & 6.1 & 6.0 & 8.2 & 1.5 & 145.9 \\
\hline Total OPEX Funded & & 26 & 9.6 & 6.0 & 20.9 & 46.5 & 43.8 & 11.6 & 31.1 & 40.9 & 18.0 & 231.0 \\
\hline \multicolumn{2}{|c|}{ TOTAL PROJECT COST } & 2.6 & 9.6 & 6.0 & 58.3 & 96.0 & 220.5 & 245.4 & 215.5 & 154.2 & 65.6 & 1073.6 \\
\hline
\end{tabular}




\subsection{Acquisition Plan}

The NIF Project will procure several hundred million dollars in materials, equipment, and services over the duration of the project. These activities will cover a broad spectrum of sizes and types of acquisitions. All procurement activities will be integrated with other project activities to ensure that hardware and services are available as required according to the top-level project schedule presented in Figure 3. DOE direct procurements (NEPA, consultants, etc.) are outside the scope of this Plan.

The participating Laboratories accomplishing these procurements will follow their DOE-approved procurement systems.

The NIF Project will review factors such as cost, schedule, efficiency, reliability, warranty, environmental, safety, and health (ES\&H), etc. when determining whether NIF project personnel should acquire components and assemble subsystems/systems, versus industry providing the complete subsystem/systems. Support of the socioeconomic (small business, small disadvantaged business, and women-owned small business) participation and competition goals will be optimized consistent with effective and efficient procurement practices.

Long-term planning and documentation will be the basis for efficient and costeffective procurements for the NIF Project. The data and supporting information contained in this Plan will be updated periodically to reflect changes approved by the NIF Project Manager to better manage and prioritize procurements in order to meet project objectives.

At present, the NIF Project has identified the following areas that may require special contract management attention:

- Contractor labor and labor agreements.

- Government-furnished equipment and facilitization.

- Overlapping of construction and special equipment installation.

\section{Quality Assurance/Quality Control}

The approved NIF Quality Assurance Program Plan ${ }^{8}$ will provide the basis for establishing quality assurance $(Q A)$ and quality control $(Q C)$ requirements to ensure compliance of NIF equipment, services, and materials with specifications. To ensure the NIF project meets or exceeds its technical goals, equipment and materials considered to be critical will have specifications and requirements providing both for in-process inspection and final inspection at the subcontractor's facilities or the construction site, as appropriate.

Government-furnished equipment (GFE) for optical inspection will be installed at the subcontractor facilities for optics $Q A$, as appropriate, with equivalent equipment 
installed in the NIF optics processing area. Performance of this equipment will be validated with qualification experiments and maintained with periodic verification tests. Experienced master opticians and engineers will source inspect optical components prior to shipment to ensure compliance with optics specifications. In addition, optics will be inspected at the NIF site on a statistical basis to confirm measurements made by the vendor. A materials review process will be established to consider optics and other components that fail to meet specifications prior to reaching a decision regarding disposition of non-conformance items.

\section{Acquisition Strategy (Summary)}

The overall NIF acquisition strategy will utilize applicable approved procurement policies and procedures. To the maximum extent practical, NIF subcontracts for supplies, equipment, and services will be awarded on the basis of competitive solicitations to responsive and responsible offerors. Fixed-price awards are the preferred contracting method and, when appropriate, cost-plus-fixed-fee (CPFF) contracts will be utilized. Cost-plus-award-fee (CPAF) and fixed-price-incentive (FPI) contracts will be considered for use if it can be determined to be in the best interest of the NIF project. Details of the use of the various contract types to minimize risk and to acquire products and services in consonance with prudent business practices to the best overall value to NIF are outlined in Section 4. Review and approval of procurement actions by the cognizant DOE contracting officer will be obtained as required by dollar thresholds set by DOE.

A subcontract for supplies, equipment, services, or construction items may be awarded without competition when there is sufficient justification for a sole-source or single-source procurement. This determination will be documented and approved by the appropriate Procurement Representative for the dollar level of the action in accordance with applicable participating laboratory procurement procedures.

Vendor source lists will be generated to maximize the number of potential sources and to obtain open competition. Qualified vendors will be identified from responses to announcements in the Commerce Business Daily or other public notices, from individual expression of interest, from knowledge developed as part of development activities in the core ICF Program, from trade literature and professional presentations, or from reviews of relevant prior procurement histories. Potential vendors will be required to demonstrate their qualifications with suitable documentation. NIF program technical personnel and procurement and material QA personnel, including Business Affirmative Action Office representatives as necessary, will visit interested new small businesses/small disadvantaged businesses to validate capabilities. All of the resulting data will be used to compile bid lists for procurement actions.

When appropriate, industry comment on NIF requirements will be sought. Presolicitation or preproposal conferences may be conducted to provide the maximum amount of information relating to the specifics of the particular procurement. 


\subsection{Description of the NIF Project Work Activities and Acquisition Strategy}

The NIF conceptual design was completed in May 1994 by the staff of the participating laboratories. Keller and Gannon contractors provided designs of the conventional facilities and equipment. The conceptual design effort included the following: criteria preparation; complete design description; Quality Assurance Program Plan; Preliminary Hazards Analysis; and detailed cost and schedule estimates.

The Conceptual Design Report was subjected to an Independent Cost Estimate review. The advanced conceptual design phase further developed the design, and is the phase in which all of the criteria documents that will govern Title I Design are reviewed and updated.

\subsubsection{Title I and Title II Design, Title III Engineering (PACE)}

Facility and Standard Equipment. Title I design of the conventional facilities and standard equipment will begin in FY96 for the NIF LTAB and OAB. As noted above, AE subcontractors for these design efforts were selected on a competitive basis. The LTAB AE subcontract was awarded in January 1996; the OAB AE subcontract is estimated to be awarded in May 1996.

Title I design will be completed by the end of FY96. Title II design of the LTAB, $\mathrm{OAB}$, and site-specific infrastructure following the NEPA ROD will be completed in FY97, producing the construction packages for the conventional facility and standard equipment. Due to the possibilities of technical changes to the special equipment to be installed in the LTAB and the schedule uncertainties in site selection, the Title I services will be provided on a cost-reimbursement basis. The work scope includes preparation of an integrated Title I design including cost estimate and schedule, Title II construction packages and backup (e.g., calculations, etc.), acceptance test procedures (ATPs), and acceptance criteria. As Title II uncertainties are expected to be reduced via Title I products, Title II and Title III services may be able to be performed under a fixed price subcontract.

Sverdrup Facilities, Inc. has been selected as the NIF Construction Manager, and a CPFF subcontract will be awarded in the third quarter of FY96. The CM will be under the technical direction of the NIF Project Office's conventional facility Associate Project Engineer. The CM will be responsible for directing the NIF facility construction subcontractors, and the standard equipment installation through acceptance test procedure (ATP) completion. The lower-tier construction subcontracts are expected to be fixed price and competitively bid.

Special Equipment. The preliminary and final designs of the NIF special equipment (lasers, power conditioning, target area equipment, etc.) will be performed by the NIF System Engineers supported by staff from the participating national laboratories and design subcontractors. The work will begin in FY96 with preliminary design complete by the end of the fiscal year and final design, including procurement packages, quantitative design bases, and acceptance test criteria and procedures, beginning in 
FY97. The in-process inspection work to support installation (e.g., resolve field issues) and preparation of as-built drawings of the installed special equipment systems will also be led by the NIF System Engineers supported by their staff and design subcontractors. Supporting subcontracts will be issued on fixed price and cost reimbursement bases, as appropriate, to the extent the work can be clearly defined.

\subsubsection{Optics Manufacturing Facilitization and Pilot Production (OPC)}

Present commercially available optics manufacturing capabilities, both in cost and capacity, are inadequate for meeting NIF cost and schedule objectives. Ongoing activities in the ICF Program will develop improved optical materials and manufacturing processes, which in turn will reduce the cost of producing large, highquality optics such as those required for the NIF. Specifically, the advanced equipment designs based on these development efforts will minimize NIF production and operating costs after installation of this equipment at the various vendors. However, the equipment capacity used in this research program will be insufficient to meet the NIF schedule requirements. Additional government-furnished equipment for NIF optics production will be required to ensure adequate capacity to meet the NIF schedule. To minimize technical and schedule risks and enhance competition, two or more vendors will be included wherever possible in each major optics area.

\section{Strategy}

At the conclusion of the optics manufacturing research program, it is expected that the facilitization pilot production and production for the each of the major optical components for the NIF will be solicited competitively. Subcontracts will be awarded to one or more companies in each component area. The selection process for facilitization will specify that any follow-on pilot and full production will be limited to facilitized firms. Similarly, if facilitization is not an issue, award of a subcontract for pilot production, and successful performance of that subcontract, will be specified as a prerequisite for a full production order.

An acquisition risk assessment and available funding will be used to determine the appropriate number of vendors to facilitize for NIF optics production. Subcontracts will be phased, with intermediate major milestones to ensure technical and schedule compliance. Follow-on work will be contingent on successful performance of preceding phases. Follow-on subcontracts may be structured as options within a single subcontract including the full range of activity from facilitization through full production, or as a series of independent subcontracts. As final production quantities may depend on pilot production experience, option pricing may be negotiated after pilot production.

For optics components in which two or more vendors have been facilitized, the split of the production order will be tied to performance and cost in pilot production. Pilot production will confirm subcontractors' capability to meet stringent production requirements and will also provide confidence prior to commitment to the higher-cost final production orders. Subcontracts will identify the criteria by which pilot 
performance will be judged in order to determine the distribution of final production order quantities.

The optics manufacturing research program will provide sufficient information to characterize the nature of the risks that will be encountered during production. Fixedprice incentive subcontracts appear to be appropriate for this phase of manufacturing, offering benefits to both the government and subcontractor in cost control and schedule risk management. Cost-type contracts will also be considered when a fixed-price contract would present unacceptable risk for the company or the government.

\subsubsection{Construction-Standard Equipment (PACE)}

Start dates of procurement activities will be staggered within a time period that will begin before $\mathrm{CD} 3$ for long-lead procurements. Site preparation will be authorized by the DOE at CD3, and will begin during the third-quarter of FY97. Facility construction will be initiated in fourth quarter of FY97 to enable construction to be completed on a schedule consistent with special equipment installation and start-up. After a successful Title II design review and approval, the Construction Management subcontractor, who is not affiliated with the $\mathrm{AE}$, will perform the following principal functions:

1. Review all designs and specifications for constructability, bidability, and clarity of the interfaces with other construction subcontracts.

2. Monitor and coordinate PMME construction subcontracts and act as the interface with the various contractors in the following areas: contract status, progress, problems; construction schedule, job safety, regulatory compliance, etc.; construction contract change orders; requests for information from the contractor relating to the intent of the drawings and specification; shop drawing processing and submitting; acceptance of the subcontract work upon completion.

3. Provide Title III inspection services for conventional facilities to verify conformance with plans and specification. Provide daily job coordination with the selected NIF site organization's security, fire department, health and safety, environmental protection, and appropriate maintenance and operations personnel to allow construction to proceed in an orderly manner.

4. Provide coordination of installation of special equipment under the technical direction of the NIF Project Office.

Beneficial occupancy of the LTAB and OAB facilities is scheduled during the third quarter of FYOO and third quarter of FY99 respectively. At this time, the major subsystems, e.g., target chamber, support structures, and other heavy construction elements must have been installed. To meet schedule requirements, this installation process will be staged to match related subsystem schedule requirements. Different sections of the facility will be available to start this process before other sections have been-completed. This phased approach will enable an earlier start on subsystem installation, permitting parallel facility construction and special equipment installation efforts. This will facilitate an earlier project completion date, but will also require appropriate contractual agreements, closely integrated project planning, and adequate, timely Project funding. 
Prior to FY99, significant subassembly work will be required. This activity will be accomplished in off-line facilities to the greatest extent possible to minimize the amount of work that will be required in the NIF LTAB facility. The NIF Project Office will determine the most appropriate method (outside vendor or site career/contract labor) for the subassembly work. Assembly work not contracted to qualified vendors will be performed by project staff and/or contract labor directly under the supervision of project staff. Subassembly contracts will be managed by the NIF Project Manager and executed according to the NIF Procurement Plan. Scheduling of these activities will be coordinated to provide timely delivery of completed subassemblies consistent with receiving, inspection, and storage capabilities of the project.

\subsubsection{Procurement and Installation-Special Equipment (PACE)}

The NIF Project will be responsible for procurement/fabrication of special equipment. Some optics procurements must be initiated during Title II in early FY97, because of the long-lead time required to manufacture the large quantity of optical elements required for NIF. Approval will be obtained from the DOE (Section 3.10) for early acquisition of these long-lead items. Long-lead items include starting materials for laser glass, the $\mathrm{KDP} / \mathrm{KD}^{* \mathrm{P}}$ crystals and fused silica optics, target chamber material, and possibly for other special supplies or equipment. Optics vendors who have the proven technical capabilities and capacity, or who have been facilitized with equipment necessary to meet NIF's production and quality requirements, will be contracted to provide the production components. Because of the specialized technology required, these efforts will be coordinated by the project's optics manufacturing group.

Other special equipment procurements will be coordinated between the NIF Project Manager and NIF Procurement after CD3 (scheduled for March, 1997). Components will be procured from qualified vendors who have been identified during detailed engineering and have demonstrated acceptable performance during component pilot production. For many subsystems, it will be cost effective to have qualified vendors assemble and test some NIF components and deliver completed subassemblies to the project. In these cases, competitive fixed-price proposals will be evaluated to select the vendor(s) offering the lowest price while meeting all specifications. Several large subsystems spanning a spectrum of manufacturing and assembly processes (e.g., target chamber, and pulse generators) are expected to be handled in this manner.

Requirements for construction spares will be included in the subcontracts for the special equipment and will be paid for with PACE funds. These spares will cover damaged components generated during the assembly and installation process. To minimize overall project costs it may be necessary in some cases to procure construction and operating spares in the same subcontract. For example, some optical components will require expensive production set-up costs, which should only be costed once. However, it may be appropriate to maintain dual sources in order to mitigate schedule risk. Operating spares required for system start-up and initial operation will be procured with OPC funds. 


\section{Strategy}

Results of the facilitization and pilot production will be used to determine the awards for optics production in cases where more than one vendor has been facilitized. To be considered for production, vendors will be required to produce engineering prototypes of NIF components that meet NIF specifications. Two or more sources will be developed wherever possible to ensure competition for production orders. As the source of funds is not germane to the subcontract process, construction and operating spares should be considered as options to be included in production subcontracts. However, accounting must be able to identify the source of funds for each acquisition.

\subsubsection{Start-up and Operating Spares (OPC)}

Start-up of the NIF will overlap with equipment assembly and installation to allow completion of the project at the earliest possible date, and to minimize total project costs. Start-up formally begins when individual components or subsystems have been installed, and are verified through acceptance testing to be operational. Equipment procurements during start-up will be minimal (approximately $\$ 200 \mathrm{~K}$ ). The primary procurement during this phase is contract labor, which will be utilized when appropriate for cost and schedule efficiency.

The majority of the special equipment spares required for start-up and initial operations will be procured and allocated during the component pilot and production subcontracts.

The start-up phase will begin in FY00. CD4 and the transition to operations will occur in late FYO2. This is the scheduled time for the completion of the operational test procedures and the final Operational Readiness Review (ORR).

Several hundred personnel will be required to support the start-up of the NIF. Some of these personnel will also be involved during the assembly and installation activities. However, it is expected that there will be inadequate Laboratory contractor staff at the designated NIF site to complete the start-up activities. Level-of-effort contracts may therefore be utilized to supplement the NIF staff, as required. After the completion of the final ORR and CD4, the NIF Project will be complete.

All special equipment spares required for start-up and initial operations will be procured with OPC funds. The procurement of spares may be closely coordinated with the primary production procurements in order to minimize redundancy in setup and other fixed costs.

\section{Strategy}

Labor contracts utilized through assembly and installation will have options for continued support through start-up and possible operations. Further details of contract labor are discussed in Section 3.10. 


\subsection{Source Selection}

\subsubsection{Methods of Obtaining Competition}

In the acquisition of unique equipment and hardware, qualified companies will be used to the maximum extent possible. It is expected that NIF will release a limited number of noncompetitive procurements. Justification and documentation for these unique procurements will be reviewed by both senior procurement and project personnel.

\subsubsection{Source Selection Procedures}

Source selection for all procurement actions will be conducted in accordance with DOE-approved policies and procedures. The preference for the award of subcontracts are as follows:

- Competitive negotiation or bid, depending on the nature of the work or item(s) being procured.

- Non-competitive negotiation.

In both cases, the objectives of NIF Project procurement procedures are to:

- Ensure fair and effective competition, where possible;

- Ensure impartial and comprehensive evaluation of offerors' proposals, as warranted by the nature of the procurement action;

- Ensure selection of the source that will provide the best value to the NIF project; and

- Minimize the cost, complexity, and cycle time of the solicitation, evaluation, and selection process.

\subsubsection{Solicitation Documentation}

The Laboratory contractors are currently in the process of modifying their procurement systems to reflect the removal of "the Federal Norm" from the DOE Acquisition Regulation as the key standard by which DOE measures procurement system adequacy. The Federal Norm, in practice, imposed many federal procedures on the conduct of Laboratory procurements, particularly in the areas of solicitation of offers and the conduct of source selections. Many Laboratory contractors, including LLNL and LANL, adopted variations on the federal model in source selections at relatively low dollar thresholds, including the use of Source Evaluation Boards and the rigorous documentation inherent in those procedures. The Laboratory contractors, in coordination with the DOE Office of Procurement and Assistance Management and their cognizant Contracting Officers, are currently in the process of redefining their procedures to reflect "best practices" as may be employed in industry or the government. 
Offers will be solicited with consideration of the nature, complexity, and/or availability of competition for each procurement, and the information required from offerors in order to determine the most advantageous offer. Some offers may be evaluated principally on the basis of price and/or delivery, which will only require a simple solicitation. More complex procurements will require more information to evaluate an offeror's capabilities, approach, or establish confidence in an offeror's potential for success relative to the competition, and a detailed subcontract is expected to result. Written solicitations detailing the project requirements, information needs, evaluation criteria, and expected subcontract terms and conditions will be used for these more complex actions. "Best value" evaluations will be performed by teams representing both technical and procurement personnel to determine the offeror providing the best combination of cost/price and qualitative merit to the NIF project. Decisions may be made on the basis of initial offers or after negotiations with one or more offerors.

Solicitation teams may be limited to a participating Laboratory Procurement representative and a cognizant technical NIF Project representative, or through groups established as formal Source Evaluation Boards. Regardless of the level of formality employed, the solicitation team will be responsible for conducting the procurement within the bounds and guidelines of the M\&O contractor's approved procurement system.

A Statement of Work (SOW) is required for all procurement actions for services and nonstandard hardware/materials. The content and detail of each SOW must fully define and describe the proposed procurement, and will vary according to the nature and complexity of the procurement. The SOW plays a key role in the subcontracting process as it serves as the basis for an offeror's response to the solicitation, and as the baseline against which to judge the subcontractor's progress and performance.

Although portions of the NIF design work will be performed at the various participating Laboratories, a significant portion will be designated for industrial firms. It is the policy of the NIF Project to actively seek to maximize industrial participation, including early involvement in the design process. With certain exceptions, the policy of the NIF Project will be to promote the use of functional or performance specifications, thereby maximizing the qualified industrial firms' freedom in achieving timely, costeffective solutions.

When practical, the NIF Project and cognizant participating Laboratory Procurement personnel will attempt to consolidate purchases and to purchase off-the-shelf like-items from a single vendor to reduce the number of orders handled, and to obtain quantity or volume discounts consistent with acceptable delivery. Consolidation decisions will be made by the NIF Project Manager with the advice of the NIF Project Engineer, the cognizant System and Lead Engineers and WBS Managers, and the responsible participating Laboratory Procurement representatives. NIF Project requirements may be grouped with other requirements at the NIF site under existing Blanket Purchase 
Orders, Basic Ordering Agreements, and multiyear procurements to maximize discounts, enhance standardization, and reduce administrative burden.

To the maximum extent practicable, all purchase orders and subcontracts for supplies, equipment, and services will be awarded on the basis of competitive solicitations to responsive and responsible offerors. Awards made on a noncompetitive basis will include justification to support such an award in accordance with applicable procurement procedures.

\subsubsection{Evaluation Criteria}

The detailed description of the scope of work, the QA requirements, the documentation requirements, and the overall NIF Project schedule requirements will be included in the SOW that is part of the solicitation package. Specific evaluation criteria will be tailored to individual procurements. Cost or price will always be a factor.

LLNL is evaluating, with DOE approval, a "best value" evaluation process deemed to be more consistent with best business practices than federally oriented. Evaluation factors may be performance based, permitting proposals to be submitted and evaluated in relation to the value derived by the Project. Such "value-related" factors should be sufficiently broad to allow consideration of unforeseen performance factors that may prove of value to the Project. Examples are:

- A markedly innovative approach to the work.

- Additional capabilities offered beyond the Project's minimum ("baseline") needs.

- Anticipated improvements in systems or technical performance.

- Qualifications of personnel.

- Solutions to operating problems.

SNL and LANL are also exploring revisions to their source-selection procedures in recognition of DOE's revised approach to contractor oversight.

More traditional criteria may be employed as in federally oriented processes, if appropriate, at LLNL or the other potential NIF sites. Examples of such criteria are technical expertise, technical understanding of the requirements, experience on similar projects, quality and experience of personnel proposed, management expertise, manufacturing capability, and probable cost.

\subsection{Vendor Qualification}

NIF procurements will span a broad spectrum of material and service contracts. The participating laboratories of the NIF Project-LLNL, SNL, LANL, and UR-LLE-have many years of experience in procuring components for large, advanced technology systems. This experience has resulted in the establishment of a proven base of vendors capable of providing many of the standard mechanical and electrical components needed for the project. This includes items such as bolts, structural material, valves, piping, resistors, circuit boards, electronic test equipment, video cameras, electronic 
power supplies, and thousands of other parts not requiring special performance specifications. Qualified vendor lists recommended by each collaborating institution will be compiled and used as a base for purchasing these standard components. Industry and laboratory standards applicable to the procurement of such items will be considered in identification and qualification of new vendors as may be determined in the course of ongoing general laboratory business operations.

Since the NIF will require many highly specialized components and services, a vendor qualification program will be exercised to identify vendors capable of successfully satisfying unique and challenging specifications. Within the core ICF Program, scientific, engineering, and production prototypes will be developed as appropriate. This equipment will be evaluated to demonstrate both component and system performance. During this process, detailed specifications and vendors qualified to meet those specifications will be identified. Flashlamps for the laser power amplifiers and metalized-dielectric capacitors required to drive those flashlamps are two examples of high-production components that will benefit from this effort. On-site vendor inspection will be performed to confirm manufacturing capabilities. Received goods will be inspected to validate compliance with all specifications. Vendors satisfactorily passing the qualification review will be appended to the approved list and be considered for future production procurements.

During the development phase of the program, subcontracts for optical components with potential vendors will be funded to develop the required vendor manufacturing capabilities. These subcontracts will include developing processing technology, enhancing and/or augmenting existing production equipment, and demonstrating manufacturing capabilities with prepilot production runs. Vendors who successfully complete this program or who have previously demonstrated the required production capabilities will be considered qualified for the production orders.

\subsection{Representative Major Contractors/Suppliers}

Appendix A contains approximately 250 names of companies that are representative of potential vendors with capabilities to provide services, materials, and equipment for the NIF Project. The list is divided into small, women-owned, small disadvantaged, and large businesses. This list will be updated periodically.

\subsection{Socioeconomic Programs}

The NIF Project will make a concerted effort to encourage the participation of small and small disadvantaged businesses, minority and women-owned businesses, and labor-surplus area businesses at all tiers of each procurernent action. The prime contracts of the project participants require that Small Business Concerns, Small Disadvantaged Business Concerns, Women-Owned Business Concerns, and Concerns located in Labor Surplus Areas shall have the maximum practical opportunity to participate in the performance of contracts awarded by NIF. Also, all subcontractors not exempted by law will be required to submit a plan for utilization of small and small 
disadvantaged business concerns as lower-tier subcontractors. However, it must be acknowledged that this project includes various state-of-the-art, intricate, large scale, complex systems or requirements which normally do not lend themselves to total subcontracting participation by these type of firms. The team members have procedures in effect that will help implement this major goal of the NIF Project. Appendix A shows that the base of potential NIF vendors has a large proportion of small business firms. It is too early to project the total percentage of dollars, but the philosophy is to competitively award to the maximum extent possible within the guidelines required by the laboratory prime contracts and as proposed in this Plan.

\subsection{Site Selection and Acquisition of Real Property}

DOE will make the site selection from existing DOE-DP owned property. There will be no additional property required at any of these sites.

\subsection{Anticipated Organizational Conflict of Interest Concerns}

The NIF Project is sensitive to the need to maintain equality in its treatment of all participants and to ensure that all interested parties have equal access to the benefits deriving from participation. Potential acquisitions will be reviewed as appropriate to determine the potential and actual organizational and conflict-of-interest situations. Action will be taken to resolve or mitigate these situations as they occur in accordance with approved procedures.

\subsection{Patents and Data}

Patents and data provisions or such other intellectual property provisions will be incorporated into subcontracts as appropriate to protect the use of DOE, UC, and project participant proprietary data and to provide for the development of any new data under these subcontracts.

\subsection{Receipts (Royalty)}

No receipts from patent royalties are currently anticipated from the NIF Project. There is a potential for some rental receipts from the commercial use of governmentfurnished equipment and facilities (Section 3.10).

\subsection{Other Information}

The following aspects not previously discussed in this Plan are important to the success of the NIF Project. 


\subsubsection{Contract Labor}

Various forms of contract labor will be used to provide temporary personnel for the Project. The personnel will include secretaries, technicians, engineers, welders, and construction workers. Two methods will be used to acquire contract labor-institutional (depending on the NIF site) and project-specific subcontracts. Institutional subcontracts are normally competed on a three- to five-year cycle and provide temporary personnel throughout the facility. These subcontracts will provide the major portion of temporary personnel needed. Project-specific subcontracts can be written as contract labor and MTAs to provide project-specific personnel and engineering design services that cannot easily or effectively be provided under the institutional subcontracts. The project specific subcontracts will be awarded by the process shown in Section 3.2 for an initial three-year period with two one-year options.

\subsubsection{Advance Procurement Request (Long-Lead Procurements)}

The NIF Project Office will provide the supporting documentation requesting authority to place long-lead procurement actions at the beginning of Title II design. The procurement actions will be for large optics, starting materials for laser glass, $\mathrm{KDP} / \mathrm{KD}^{*} \mathrm{P}$ crystals and fused-silica optics, target chamber material, and possibly for other special supplies or equipment. The documentation will provide the justification for each item and the impact if authority is not provided. The submittal will follow DOE Order 430.1 when it is implemented in LLNL's prime contract, and will be submitted to the NIF DOE Field Office for approval.

\subsubsection{Other Optics Considerations}

NIF optics occupy a unique niche and are not a main commercial thrust for many of the qualified vendors. These medium-size, high-precision optics with high-damagethreshold requirements have only a few qualified vendors for each optic type. Most of these vendors are small to medium in size with 50 to 400 employees. NIF optic orders will generally dominate the vendors' other business and represents a risk to the vendors and NIF.

Government-furnished equipment will be needed to minimize vendor and NIF Project risk to reasonable levels to the vendors and NIF. Government property clauses including property accounting and control will be incorporated into the awards to the optic vendors. Each award will be evaluated for the potential for the maximum return for any commercial usage (rent back) of the enhanced facilities or government-furnished property (GFP) that develops. At present, the rent back potential is considered to be low due to the uniqueness of the NIF optics. Also, prior to the award, determinations will be made as to the most appropriate and beneficial disposal of the government-furnish equipment and enhanced facilities when the NIF Project is completed. 


\subsection{Non-Government Participation}

A representative listing of private industry contractors is provided in Appendix A. The NIF Project is committed to a substantive involvement of industry in the design and manufacturing of the equipment and supplies necessary for its construction and operation. 


\subsection{Project Risks}

The NIF has technical, cost, and schedule risks, which are described at the overall project level in the NIF Project Execution Plan. This Plan considers the significant acquisition-related technical, cost, and schedule risks, proposing the strategy to minimize these risks.

The four main sources of NIF Project acquisition risk will be:

1. Uncertainties in the future level of funding and interruptions in funding flow.

2. Lack of sufficient budget authority to permit the most cost effective contracting.

3. Limited vendor base for specific special equipment components (e.g., optics and power conditioning).

4. The need to have overlapping construction, installation, and start-up activities to achieve schedule goals, which can lead to interferences among the various on-site subcontractors trying to complete construction and install and check out equipment. The Construction Manager will play a primary role of coordination and planning to reduce interferences to a minimum.

The NIF Project Management Team will mitigate risk through the selection and close monitoring of highly qualified subcontractors. Subcontract types will be selected based upon a predetermination of best value to the university and government and fairness to the subcontractor.

A fixed-price subcontract provides the best cost control as long as there is a welldefined fixed scope of work and good industrial experience base for the required activities by putting the risk for cost performance on the subcontractor. This type of contracting approach can be used in the design and fabrication procurements of facility and conventional hardware elements. However, it is anticipated that the NIF Project will also utilize a negotiated fixed-price approach for the fabrication of the major special and engineered equipment subcontracts. This negotiated fixed-price fabrication will be established after the design and development phases are accomplished on a cost-type subcontract.

With expected funding limitations, work awarded on a fixed-price basis will be constrained to that which can be defined, negotiated, and paid for within currentlyavailable funds. Work that cannot be segregated into discrete packages that can be completed with the funds available for obligation at time of subcontract award is not amenable to fixed-price contracting. Logically connected follow-on work could necessarily be treated as unpriced options to the initial subcontracts, or as separately negotiated sole source subcontracts. In both of these scenarios, the initially funded work will bear the brunt of nonrecurring costs for development, tooling, and other subcontractor startup costs, thus increasing unit costs for either pilot production or initial full production. If options are included, as contemplated for optics procurements, 
follow-on production should be at a reduced unit cost. If options are not provided for in the initial award, or if pricing has to be negotiated after completion of pilot production, the NIF Project will have reduced negotiation leverage over what would be available even in marginally competitive procurements.

The NIF Project will utilize CPFF subcontracts where the scope of work is not amenable to a firm-fixed-price (FFP) subcontract, either through uncertainties inherent in the scope or where uncertain yearly funding cannot be accommodated through options or segregated work as discussed above. Cost-type subcontracts are anticipated because of the developmental nature of the NIF in which some components and systems are expected to approach or exceed the current technological capabilities. Costtype subcontracts are being used for the LTAB AE firms and are contemplated for the $O A B A E$ work that has to accommodate technology improvements and possible sponsor requirement changes in the design of the NIF. Such subcontracts will also be used for specific special equipment procurements where the requirements are closely tied to technology developments.

Notwithstanding the contractual vehicle selected, the NIF Project is a national collaborative effort involving a number of major institutions. The NIF Project Manager, the Deputy Project Managers representing each participating organization, and responsible Procurement representatives must exercise judicious control that allows each participant to operate efficiently while at the same time integrate and centralize the acquisition process. To achieve these goals and subsequently minimize overall programmatic risk, the NIF Project has implemented a Configuration Management Plan. ${ }^{9}$ It provides the process for establishing documented design requirements and controlling changes to that baseline for the life of the project.

\subsection{Technical Risk}

The technical risks related to acquisition will be minimized by the following:

- Utilizing the responsible participant's technical expertise and previous procurement experience.

- Developing and approving a set of tiered design criteria, which will be baselined and then controlled throughout the design process through the Configuration Management System.

- Identifying qualified sources.

- Maintaining appropriate quality assurance and control procedures.

- Monitoring the work by the responsible participant's technical and administrative personnel.

Each of the major laboratory participants (LANL, LLNL, SNL and UR-LLE) have been involved in the development, design, and procurement of major laser fusion devices for many years. As a result of their experience, each participant is able to identify the critical items that it must be cognizant of and oversee. This in-depth 
experience has also enabled the major participants to identify those areas in which the national laboratories have the necessary expertise and those areas in which industry has the expertise.

The industrial firms that will be awarded NIF contracts must have demonstrated capability in providing similar services for complex scientific projects. This demonstrated capability will include the systems and disciplines to perform the tasks and activities assigned. Where appropriate, solicitations will include a detailed description of the qualifications required to be considered responsive. Additionally, pre-award surveys will be conducted as necessary to confirm the apparent successful offerer's capabilities. An effective quality assurance program will be considered as necessary in solicitations and resulting subcontracts.

\subsection{Cost Risk}

The Title I Design is the first step in establishing the basis for a high-confidence cost estimate. This estimate is subject to DOE Independent Cost Estimating review. In the minimization of procurement cost risks, due to the developmental nature of some NIF Project special equipment components, use of fixed-price type contracts during the design phases is probably not feasible. Instead, the NIF Project will utilize-cost-type subcontracts with fixed-fee for these phases. The challenges to effective use of the contracting method have already been addressed. Cost and technical risk to the NIF Project will be further minimized by the use of scientific prototype development, laser technology development, optics manufacturability development, and material testing programs that allow broad industry participation. In this way, the opportunity to use fixed-price type subcontracts (or options to subcontracts initiated with facilitization or pilot production) for the fabrication phase will be maximized. In specific instances, prequalification of suppliers may also be used. Finally, detailed project schedules will be required from selected subcontractors consistent with NIF Project requirements. Frequent monitoring of subcontractor performance by progress reports and on-site visits against these schedules will provide early visibility of developing cost, technical, and schedule problems.

A separate plan has been developed for the optics system manufacturing readiness (NIF Manufacturing Readiness Plan). ${ }^{10}$ The tasks to develop the vendor base for NIF Optics include laser-glass melting technology, KDP/KD*P crystal growth, and opticalcoating fabrication.

\subsection{Schedule Risk}

Schedule risk will be minimized by realistic planning, development of detailed project schedules, identification of Project milestones, and frequent monitoring of subcontractor performance against those schedules and milestones. Once the subcontract is awarded, the Project will maintain close surveillance of the subcontractor's performance. Multiple subcontracts may be awarded when necessary to 
assure total quantity or to meet required delivery milestones. If necessary, the NIF Project will assign a resident engineer to the subcontractor's facility during the fabrication phase or on an intermittent schedule as appropriate. 


\subsection{Reporting}

The NIF Project Office will be responsible for collecting, maintaining, and integrating sufficient information to satisfy all of the project management reporting requirements.

Each project participant shall maintain complete financial data at all WBS levels for assigned work. At WBS Level 2 or lower, as appropriate, monthly and cumulative planned versus actual costs and commitments, with estimates to complete, will be reported to the NIF Project Office by the 10th work day after the end of the reporting period. At the same time, each participant shall also report monthly technical and schedule progress toward work completion as of the end of each calendar month. The NIF Project Office will prepare and distribute monthly and quarterly reports to the DOE based on the integration of monthly information obtained from all project participants.

Vendor/contractor cost and schedule reporting will be required as necessary (primarily monthly) to meet good project management guidelines and the reporting milestones of the NIF Project. Basic formats will be developed for cost and fixed-priced contracts and will be incorporated into definitized purchase orders/contracts. 


\subsection{Notes and References}

1. Project Charter for the National Ignition Facility Conceptual Design, NIF-LLNL-93-396, March 1993.

2. Memorandum of Understanding Regarding the relationship between the Office of the National Ignition Facility and the Office of Research and Inertial Fusion, NIF-LLNL-95-331, March 27, 1995.

3. National Ignition Facility Project Execution Plan (Draft), NIF-LLNL-96-045, December 1995.

4. National Ignition Facility Functional Requirements/Primary Criteria, Revision 1.4, NIF-LLNL-96-058, February 1996.

5. National Ignition Facility Conceptual Design Report, NIF-LLNL-94-113, March 1994.

6. National Ignition Facility Conceptual Design Scope and Plan, NIF-LLNL-93-043, January 1994.

7. National Ignition Facility Core Science and Technology Development Plan for Indirect-Drive ICF Ignition, UCRL-ID-117076 Rev. 1, L-17588-3, December 1995.

8. National Ignition Facility Quality Assurance Program Plan, NIF-LLNL-95-499, September 1995.

9. National Ignition Facility Configuration Management Plan, NIF-LLNL-96-70, January 1996.

10. Manufacturing Readiness Plan for the National Ignition Facility, NIF-LLNL-94-204, April 1994. 


\title{
Appendix A. Representative major subcontractors/suppliers.
}

\author{
Small Businesses \\ Adams and Smith Inc.-Pleasant Hill, CA \\ Adept Manufacturing Co.-Costa Mesa, CA \\ Advance Engineering-Gardena, CA \\ Advanced Ground Systems-Anaheim, CA \\ Aero Design-Newport Beach, CA \\ Aero-Space Welding \& Machining Inc.-Milipitas, CA \\ Aerovox Industries Inc.-New Bedford, MA \\ Ahaus Tool Company Inc.-Richmond, IN \\ Aladdin Heating Corp.-San Leandro, CA \\ Albert C. Martin \& Associates-Los Angeles, CA \\ Alkurt Metals-Oakland, CA \\ All Weld Machine \& Fab-Milpitas, CA \\ Allied Engineering \& Production Corporation-Alameda, CA \\ Alpase Inc.-Downey, CA \\ Americom Electronics Corp.-Hayward, CA \\ Ametek-Newark, Delaware \\ Analog Device-Norwood, MA \\ Angenieux Inc.-Hudson, NH \\ Applied Optics-Pleasant Hill, CA \\ Apsco Mfg. Co.-San Leandro, CA \\ Aracor-Sunnyvale, CA \\ Associated Machine-Santa Clara, CA \\ Astro Model Development Corp.-Eastlake, $\mathrm{OH}$ \\ Austin Industries-Livermore, CA \\ Aydin Corp.-San Jose, CA \\ Baedal Inc.-Harrison City, PA \\ Balzers Corp.-Fremont, CA \\ Bearing Engineering-San Leandro, CA \\ Beimer Machine Works, Inc.-Livermore, CA \\ Bell Metal Fabs-Oakland, CA \\ Best Tool Company-Torrance, CA \\ Big Sky Laser Corp.-Bozeman, Montana \\ Big Sky Software Corp.-Bozeman, Montana \\ Bolt Beranek Newman-Cambridge, MA \\ Bond Optical-Lebanan, NH \\ Bostrom-Bergen Metal Productsz-Oakland, CA \\ Brear and Associates (Coastal Iron Works) \\ BRIO Research-Tuscan, Arizona
}


Small Business (cont.)

California Engineering Contractors-Mountain View, CA

Calorimetric Inc.-Boulder, $\mathrm{CO}$

Caral Inc., c/o Kue-Ken-Albany, CA

Cardon Instruments $\mathrm{Co}$.-Colchester, England

Chalet Tool Co.-Alameda, CA

Champ Company, The-Campbell, CA

Christie Contructors, Inc. - Emeryville, CA

CL Norton Co., Inc.-So. San Francisco, CA

Cleveland Crystals Inc. (CCl)-Cleveland, $\mathrm{OH}$

Coherent Inc.-Palo Alto, CA

Coleman Precision Mfg. Co.-San Jose, CA

Coleman/Fabro, Inc.-Morgan Hill, CA

Continental Optical Co.-Hauppauge, NY

Contraves-Goerz Corp.-Pittsburgh, PA

Cryneco

Cryogenic Experts Inc.-Northridge, CA

Crystal Mark-Glendale, CA

CTI Cryogenics Inc., Div. Helix Tech.-Santa Clara, CA

Current Products Inc.-Orange, CA

Cylinder Optics Inc.-Garden City, Missouri

D\&H Manufacturing-Santa Clara, CA

D\&M Machine-Campbell, CA

Delmonte Electric Co., Inc.-Hayward, CA

Design Optics Inc.--Long Beach, CA

Dezurik-Oakland, CA

Diamond Tool Co.-Oakland, CA

DRF Associates-San Diego, CA

E.G. Smith Products Inc.-Milipitas, CA

Edwards Enterprises-Newark, CA

Eimco Process-Salt Lake City, UT

Electronics Metal Finishing Inc.-Colorado Springs, CO

Enterprise Roofing Service Inc.-Concord, CA

Equipto Inc.-Aurora, IL.

Evergreen Industries-Lynnwood, WA

Ferrero Electric Co.-Merced, CA

Ferson Optics-Ocean Springs, Miss.

Fisher Scientific-Santa Clara, CA

Floating Point Systems Inc.-Mountain View, CA

Flying Machine-Livermore, CA

Ford Construction Co. Inc.-Lodi, CA

Franklin High Voltage Corp.-Escondido, CA

G.S. Kinney Vacuum Co. - Canton, MA

Galileo Electro-Optics Corp.-Sturbridge, Maine

Gar Electro Forming Inc.-Danbury, CT 
Small Business (cont.)

GCI-Martinez, CA

Gem City Engineering Co.-Ohio

General Tool Co.-Cincinnati, $\mathrm{OH}$

Glass Fabricators Inc.-Rochester, NY

GNB Corporation-Hayward; CA

Grinnell Fire Protection Systems Inc.-Burlingame, CA

H-P Machinery-Campbell, CA

Hammon Plating-Palo Alto, CA

Harbor Island Machine Works-Seattle

Harper-Leader In-Waterbury, CT

Helfrecht Corp.-Traverse City, MI

Hem Saw-Pryor, Oaklahoma

Hextek-Tuscan, Arizona

Hi-Tec Precision Fab-Livermore, CA

Hogan-Escalon,CA

Hugin Industries-Los Altos, CA

Hyspan Precision Products Inc.-Chula Vista, CA

IKO International-Torrance, CA

ILC Technology Inc.-Sunnyvale, CA

Inrad-Northvale, NJ

Integrated Software Co.-San Diego, CA

Intrepid Enterprises-Santa Clara, CA

IT \& T Electro Optical Products Div.-Fort Wayne, IN

J \& K Builders-Novato, CA

J-3 Associates-San Jose, CA

J.A. Woollam Co.-Lincoln, Nebraska

James L. Whittaker Inc.-Concord, CA

Janos Technology Inc.-Townshoud, Vermont

Johnson Plating Co.-Oakland, CA

K.O. Lee Co.-Aberdean, South Dakota

Keehner Manufacturing Co.-San Leandro, CA

Kenlab-San Leandro, CA

Keuffel \& Esser Co.-So. San Francisco, CA

Kiewit Pacific Co.-Concord, CA

Kigre Inc.-Hilton Head, S.C.

Kilsby-Roberts Co.-Hayward, CA

Kinetic Systems-Lockport, IL

Klinger Scientific Corp.-Mt. View, CA

La Croix Optical-Babesville, Arkansas

Lawson Mechanical Contractors-Sacramento, CA

Lightning Optical - Tarpon Springs, Florida

Lintech Corp.-Monrovia, CA

Lodi Tent \& Awning Co.-Lodi, CA

Lord Corp. Hughson Metals-Pittsburgh, PA 


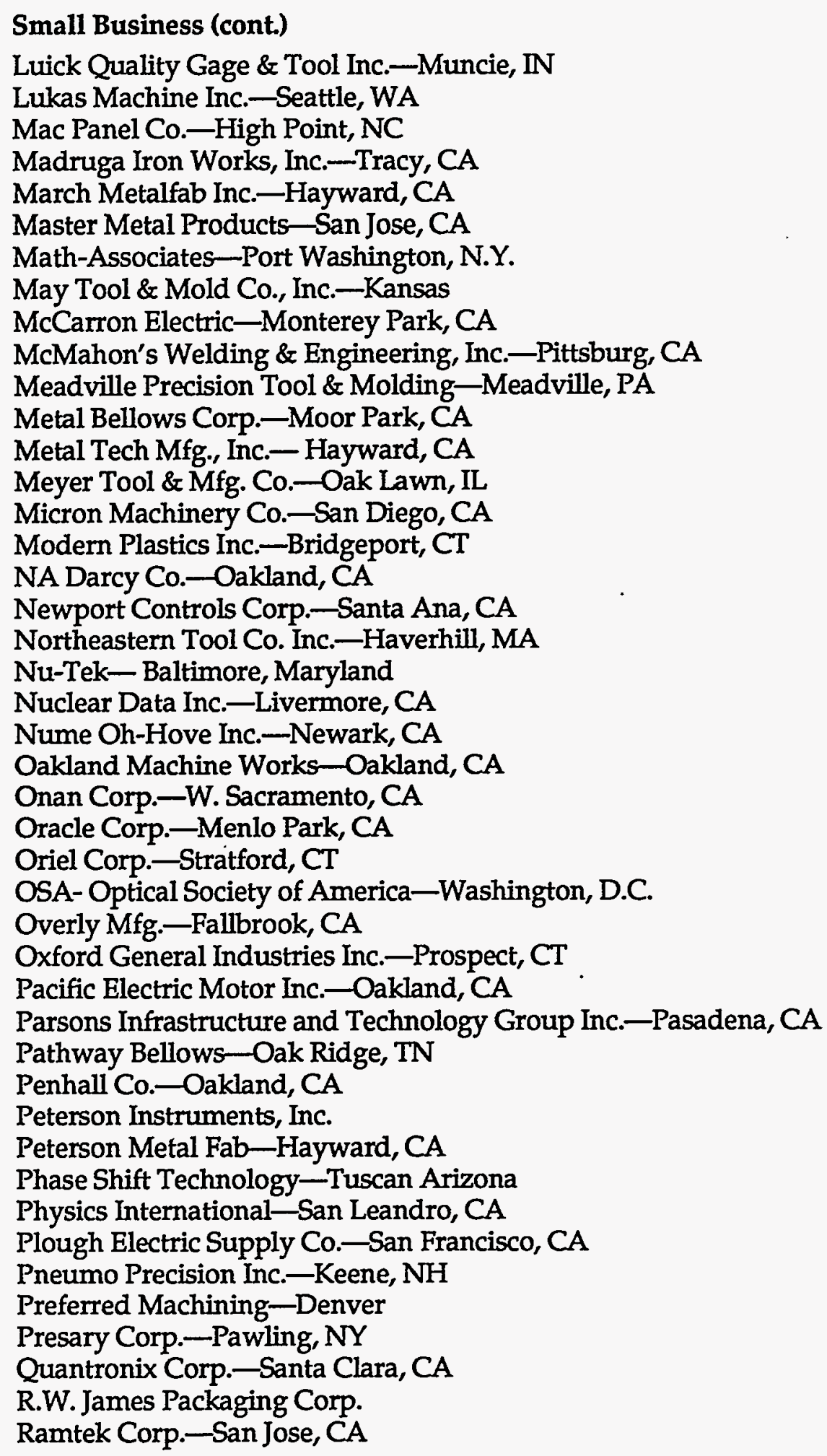




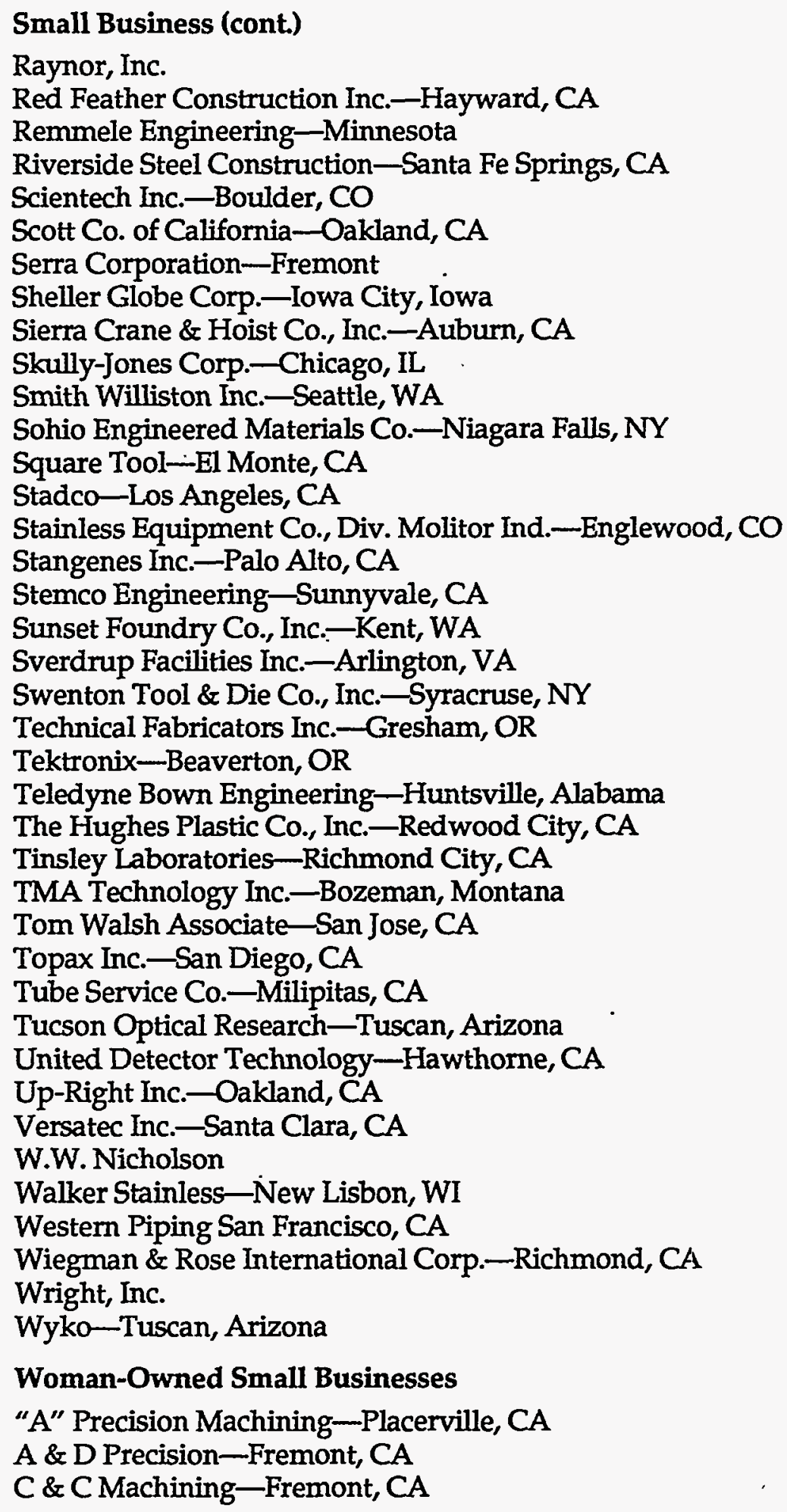




\section{Woman-Owned Small Businesses (cont.)}

Creative Machine

D \& M Machine-Campbell, CA

Gardner Machine Products-San Jose, CA

$\mathrm{H}$ \& K Manufacturing Co., Inc.-Dublin, CA

Hytech Engineering-Pleasanton, CA

Jona Machine-Los Alamos, NM

KC Precision-Fremont, CA

Lukas Fab., Inc.-Seattle,WA

McMahon's Welding and Engineering Inc.-Pittsburg, CA

Meyer Tool and Mfg.-Oaklawn, Il

Meyer Tool-Chicago, IL

P \& K Tool \& Production-Hayward, CA

Precision metal Fab-Hayward, CA

Process Equipment-Ohio

Red Feather Construction Inc.-Hayward, CA

Stangenes Inc.-Palo Alto, CA

Streetman Precision-Sacramento, CA

Tapemation Machining-Scotts Valley, CA

Terminal Manufacturing-Berkeley, CA

Thomas Tool \& Mfg.-Pleasanton, CA

\section{Small Disadvantaged Businesses}

A \& D Welding-Rancho Cordova, CA

A.V.D. Metal Fab, Inc.-Hayward, CA

Aircraft Engineering-Paramount, CA

Americom Electronics Corp.-Hayward, CA

Applied Optics-Garden Grove, CA

APV Manufacturing \& Engineering-Garden Grove, CA

Argus Manufacturing-San Jose, CA

Bell Machine \& Fab-Shreeveport, LA

Bell Machine-Shreeveport, LA

D \& M Machine-Campbell, CA

Dynatec Manufacturing-San Jose, CA

Gulf Coast Alloy-Texas

Hytech Precision-Fremont, CA

Lukas Fab-Seattle, WA

Lukas Fab., Inc.-Seattle, WA

M\&T, Inc.-Riverside, CA

Master Metal Manufacturing-Oregon

Omega Fab-Gardena, CA

R \& J Tool \& Manufacturing-Livermore, CA

Reycor Precision Welding-Illinois

Syncro-Vac-Milpitas, CA

Terminal Manufacturing-Berkeley, CA 
Small Disadvantaged Businesses (cont.)

Topete Tool-Santa Clara, CA

\section{Large Businesses}

Abacus Electronics Co., Inc.-Mountain View, CA

Acton Research-Acton, MA

Aerojet Electro Systems, Co.-Azuza, CA

Aerotech Inc.-Pittsburgh, PA

Airtron Div. of Litton Systems, Inc.-Morris Plains, NJ

A.L. Johnson Co.--Sunnyvale, CA

Allen Bradley Electronics Lts. - Tyme \& Ware, England

Alliance Tool Corp.-Rochester, NY

Allied Engineering \& Production Corp.-Alameda, CA

Allied Signal-Kansas City, KN

Bechtel National Inc.-San Francisco, CA

Boeing-Seattle, WA

Chicago Bridge \& Iron (CBI) Fabrication-San Francisco, CA

Coors Porcelain Co.-Golden, $\mathrm{CO}$

Corning Glass Works-Corning, NY

C. Overaa \& $\mathrm{Co}$.-Richmond, CA

-Digital Equipment Corp.-Alameda, CA

Dresser Industries-Walnut Creek, CA

Eastman Kodak Co.-Rochester, NY

E G\&G Inc.-Wellesley, MA

Fluorocarbon U.S. Quartz Div.-Sunnyvale, CA

FMC-San Jose, CA

General Atomics-San Diego, CA

General Electric-Chattanouga, TN

General Electric Co. Capacitor Div.-Hudson Falls, NY

General Electric Service Shop-Machining

Heraeus Amersil Inc.-Sayreville, NJ

Hewlett Packard-Palo Alto, CA

Hoya Optics-Fremont, CA

Hughes Aircraft-Long Beach, CA

Kaiser-Oakland, CA

Kodak-Rochester, NY

Litton Itek-Lexington, $\mathrm{MA}$

LTI-Palos Verdes, CA

Martin Marrietta Energy Systems, Inc.-Oakridge, TN

Máxwell Laboratories Inc.-San Diego, CA

Optical Coating Laboratory Inc.-Santa Rosa, CA

Owens Illinois Inc--Toledo, $\mathrm{OH}$

Perkin-Elmer Corp.-Garden City, CA

Process Equipment-Anaheim, CA

Quantel International Corp.-Santa Clara, CA 
Large Businesses (cont.)

Raymond Kaiser Engineers-Oakland, CA

RCA-Lancaster, PA

Reynolds Metals Co.-Richmond, VA

Rockwell International-Golden, $\mathrm{CO}$

SAIC-San Diego, CA

Schott Glass Technologies-Oakland, CA

Spectra Physics-Mountain View, CA

Stadco

TRW-Redondo Beach, CA

Union Carbide-Washougal, Washington

Varian Associate-Palo Alto, CA

Weldon International-Bridgman, MI

Westinghouse Marine Division-Sunnyvale, CA

Westinghouse R\&D Center-Pittsburg, CA

Zygo Corporation-Middlefield, CT 
